Ewa JURGA-WOSIK

Uniwersytet im. Adama Mickiewicza, Poznań

\title{
Analiza porównawcza służby cywilnej w Polsce i w instytucjach Unii Europejskiej (stan prawny - grudzień 2008 rok)
}

$S_{\text {dobnym procesom. Kolebką idei służby cywilnej jest Francja (okres }}^{\text {łużba cywilna w Polsce i w instytucjach Unii Europejskiej podlega po- }}$ III Republiki) i stąd systemy administracyjne w Europie Zachodniej (i nie tylko) czerpią przykłady ${ }^{1}$. W literaturze przedmiotu wyróżnia się dwa podstawowe modele zatrudnienia w służbie cywilnej - model kariery oraz model stanowisk (pozycyjny), chociaż w praktyce częściej występuje model mieszany ${ }^{2}$. Polski model służby cywilnej można określić jako mieszany z przewagą uregulowań właściwych dla modelu kariery. W modelu kariery podmiotem zatrudniającym urzędnika jest państwo. Urzędnik jest przyjmowany do korpusu służby cywilnej albo do jednej z kategorii tego korpusu (na najniższe stanowisko), a nie na konkretne stanowisko. Jego stosunek zatrudnienia jest bardzo stabilny - trwa, aż do przejścia na emeryturę. W tym czasie realizuje się w kolejno występujących po sobie stopniach kariery. Państwo gwarantuje urzędnikowi precyzyjnie uregulowane uposażenie i emeryturę lub rentę. Takie rozwiązania zbliżone występują we Francji, Niemczech, Austrii i zostały zmodyfikowane na rzecz specyfiki funkcjonowania urzędników w instytucjach Unii Europejskiej (tzw. model kariery zamknięty) ${ }^{3}$. W modelu stanowisk, podmiotem zatrudniającym urzędnika jest konkretny urząd, a nie państwo jako całość. Jest on zatrudniany na konkretnym stanowisku, a nie w korpusie cywilnym „w ogóle”. Słabsza jest stabilność stosunku pracy oraz gwarancje wyna-

1 Prawo urzędnicze, pod red. T. Liszcz, Lublin 2005, s. 16.

2 J. Czaputowicz, Stużba cywilna w procesie integracji europejskiej, w: Administracja publiczna. Wyzwania $w$ dobie integracji europejskiej, pod. red. J. Czaputowicz, Warszawa 2008, s. 272-274.

3 M. Małecki, K. Tomaszewski, Status urzędnika Unii Europejskiej, Warszawa 2005, s. 15 . 
grodzenia. Rozwiązania bliskie temu modelowi występują m.in. w Wielkiej Brytanii, krajach skandynawskich i we Włoszech.

W Polsce idea służby cywilnej pojawiła się w II Rzeczpospolitej, w ustawie z dnia 17 lutego 1922 r. o państwowej służbie cywilnej (Dz. U. Nr 21, poz. 164), nowelizowanej kilkanaście razy przed wojną i po wojnie (tekst jedn. Dz. U. 1949, Nr 11, poz. 72) ${ }^{4}$. Ponadto służba cywilna w Polsce była unormowana w następujących ustawach: z dnia 16 września $1982 \mathrm{r}$. o pracownikach urzędów państwowych (tekst jedn. Dz. U. 2001, Nr 86, poz. 953 ze zm.); z dnia 18 grudnia 1998 r. o służbie cywilnej (Dz. U. 1999, $\mathrm{Nr} 49$, poz. 483) oraz z dnia 5 lipca 1996 r. ustawa o służbie cywilnej (Dz. U. 1996, Nr 88, poz. 402 ze zm.). Obecnie podstawą prawną jest ustawa o służbie cywilnej z dnia 24 sierpnia 2006 r. (Dz. U. 2006, Nr 170, poz. 1218 ze zm.). Wydaje się jednak, że los tego aktu jest przesądzony, ze względu na trwające prace nad nowelizacją ustawy o służbie cywilnej i powrotem do wielu rozwiązań zawartych w ustawie z 5 lipca 1996 roku. Innymi aktami dotyczącymi służby cywilnej są m.in. zarządzenie $\mathrm{Nr} 81$ Prezesa Rady Ministrów z dnia 1 sierpnia 2007 r. w sprawie zasad dokonywanych opisów i wartościowania stanowisk pracy w służbie cywilnej (M.P. z dnia 9 sierpnia 2007 r.), rozporządzenie Prezesa Rady Ministrów z dnia 21 grudnia 2006 r. w sprawie postępowania wyjaśniającego i postępowania dyscyplinarnego w służbie cywilnej (Dz. U. 2006, Nr 246, poz. 1798), rozporządzenie Prezesa Rady Ministrów z dnia 24 stycznia 2007 r. w sprawie sposobu przeprowadzenia postępowania kwalifikacyjnego w służbie cywilnej (Dz. U. 2007, Nr 13, poz. 82 ze zm.), rozporządzenie Prezesa Rady Ministrów z dnia 9 lutego 2007 r. w sprawie określenia stanowisk urzędniczych, wymaganych kwalifikacji zawodowych, stopni służbowych urzędników służby cywilnej, mnożników do ustalenia wynagrodzenia oraz szczegółowych zasad ustalania i wypłacania innych świadczeń przysługującym członkom korpusu służby cywilnej (Dz. U. 2007, Nr 12, poz. 79) oraz rozporządzenie Prezesa Rady Ministrów z dnia 5 kwietnia 2007 r. w sprawie szczegółowych zasad przeprowadzania ocen urzędników służby cywilnej (Dz. U. 2007, Nr 69, poz. 453).

Prawną podstawą europejskiej służby cywilnej jest artykuł 283 Traktatu o utworzeniu Wspólnoty Europejskiej. W myśl tego zapisu - Rada

4 Ustawa obejmowała nie tylko urzędników i niższych funkcjonariuszy państwowych (np. woźnych), zatrudnionych w administracji rządowej, lecz także w innych urzędach państwowych, w szczególności w Kancelariach Sejmu i Senatu oraz w Cywilnej Kancelarii Prezydenta RP. 
działając przy użyciu kwalifikowanej większości głosów na podstawie propozycji Komisji i po przeprowadzeniu konsultacji z innymi zainteresowanymi instytucjami przyjmuje Regulamin Pracowniczy Funkcjonariuszy Wspólnot Europejskich oraz warunki zatrudnienia innych pracowników Wspólnot ${ }^{5}$. Podstawą funkcjonowania urzędników jest zatem Regulamin Urzędniczy, który od 1968 r. był nowelizowany ponad dziewięćdziesiąt razy $^{6}$. Zmiany te wynikały m.in. z procesu rozszerzenia UE o nowe państwa członkowskie, ale też z konieczności uwzględnienia świąt państwowych, nowych zasad ubezpieczenia zdrowotnego oraz transferu płac dla urzędników z nowych państw członkowskich. Regulamin Urzędniczy zawierał rozwiązania administracyjne przejęte z państw założycielskich - głównie Francji, Niemiec i krajów Beneluksu. Model ten charakteryzował się przywiązaniem do procedur administracyjnych i hierarchii oraz brakiem elastyczności w podejmowaniu nowych działań. Dopiero po trzydziestu trzech latach funkcjonowania przepisów urzędniczych zaproponowano radykalne zmiany, a bezpośrednią przyczyną było przygotowanie instytucji UE na przyjęcie nowych państw do Wspólnoty. Wpływ niewątpliwie miały także niechlubne wydarzenia - skandale korupcyjne, których konsekwencją było rozwiązanie Komisji pod przewodnictwem Jaquesa Santera. Reforma unijnego systemu służby cywilnej została zapoczątkowana w marcu 2000 roku przez komisarza ds. administracji Neila Kinocka ${ }^{7}$. W Białej Księdze zatytułowanej Reforma Komisji zawarto cele reformy, a więc - usprawnienie systemu zarządzania finansami, kontroli i audytu finansowego, wprowadzenie nowego systemu planowania strategicznego oraz modernizacja polityki w zakresie rozwoju zasobów ludzkich ${ }^{8}$. Ten ostatni składał się z czterech pakietów. Pierwszy pakiet koncentrował się na poprawie kontroli wewnętrznej i finansowej, drugi zawierał propozycje dotyczące dyscypliny pracy i równych praw zatrudnienia dla wyższej kadry zarządzającej oraz określał, z których zadań Komisja ma zrezygnować, trzeci - obejmował działania związane z zasobami ludzkimi - rekru-

${ }^{5}$ Pełna nazwa aktu regulującego prawo urzędnicze Unii Europejskiej brzmi - Rozporządzenie w sprawie kadr urzędniczych Wspólnot Europejskich oraz rozporządzenie w sprawie warunków zatrudnienia innych pracowników Wspólnot Europejskich. Rozporządzenia w formie jednolitego aktu obowiązują od 5 marca 1968 roku.

${ }^{6}$ Autor stosuje w publikacji uproszczoną nazwę - Regulamin Urzędniczy.

7 J. Czaputowicz, Stużba cywilna w Instytucjach Unii Europejskiej, „Służba Cywilna" 2003, nr 6, s. 37-66.

${ }^{8}$ J. Czaputowicz, Stużba cywilna w procesie integracji europejskiej, op. cit., s. $271-272$. 
tację, szkolenia, ocenę i mobilność pracowników, a czwarty - nowe propozycje w zakresie ścieżki kariery oraz systemu wynagrodzeń i emerytur. Opracowano też nowe procedury kontroli przestrzegania standardów etycznych. Zakres reformy obejmował - stworzenie kultury służby cywilnej i przyjęcie kodeksu etycznego, uproszczenie procedur administracyjnych, skrócenie terminów płatności, lepsze wykorzystanie technologii informatycznych, także właściwe określenie priorytetów i efektywne wykorzystanie zasobów poprzez wprowadzenie systemu zarządzania opartego na aktywności, zwłaszcza cyklów strategicznego planowania i programowania, co ma ułatwić dostosowanie środków do zadań oraz sprawowanie przez Komisję politycznego kierownictwa nad administracją. W tym kontekście - również przegląd zarządzania finansami, wzmocnienie kontroli (stworzenie systemu wewnętrznego audytu) oraz modernizacja polityki w zakresie zarządzania zasobami ludzkimi ${ }^{9}$.

Reforma administracji instytucji UE obowiązująca od 2004 roku objęła obszary związane z zarządzaniem zasobami ludzkimi, takie jak rekrutacja, konkursy na stanowiska, klasyfikacja urzędników, system ocen i promocji, szkolenia oraz kwestie etyki urzędniczej ${ }^{10}$. Komisja Europejska określiła, że kariera urzędników zatrudnionych w instytucjach UE powinna zależeć od wyników ich pracy i potwierdzonych kwalifikacji, a nie od stażu i wieku pracownika - jak było dotychczas. Reforma również uwzględniła postanowienia Karty Praw Podstawowych, zgodnie z którymi obywatel Unii Europejskiej posiada prawo do dobrej administracji (art. 41), a jego sprawy powinny być rozpatrywane bezstronnie. Karta zabrania dyskryminacji ze względu na wiek (art. 21), co wymagało zniesienia praktykowanego maksymalnego wieku kandydatów (45 lat) ${ }^{11}$. Podobny zapis o zasadzie niedyskryminowania zawiera Europejski Kodeks Dobrej Praktyki Administracyjnej (art. 5) ${ }^{12}$.

Zarówno w Polsce, jak i w instytucjach Unii Europejskiej podstawowym celem utworzenia korpusu służby cywilnej jest wykształcenie profesjonalnej, rzetelnej, politycznie neutralnej i bezstronnej grupy

9 Obecnie kwestie te reguluje - Oświadczenie dotyczące przestrzegania ładu administracyjno-regulacyjnego wydane przez Komisję, Bruksela 2007.

$10 \mathrm{http} / / /$ europa.eu.int/comm/reform/2002/chapter07_en.htm, odczyt 2005.

11 http://www.ms.gov.pl/ue/translation/32000X1218(01).doc, odczyt 2008.

12 Europejski Kodeks Dobrej Praktyki Administracyjnej, „Wspólnoty Europejskie" 2005. 
urzędniczej $^{13}$. Idea jest podniosła, ale praktyka funkcjonowania służby cywilnej wskazuje na pewne odstępstwa od reguły. Dowodem są nie tylko wnoszone skargi na funkcjonowanie administracji, ale też badania ankietowe przeprowadzone wśród urzędników, którzy poświadczają, iż poddawani są różnego rodzaju naciskom, najczęściej politycznym ${ }^{14}$. Urzędnicy wchodzący w skład korpusu służby cywilnej podlegają ograniczeniom w celu zapewnienia neutralnego politycznie $\mathrm{i}$ bezstronnego wykonywania przez nich zadań państwa czy instytucji UE ${ }^{15}$. Ustawodawca w Polsce nałożył w szczególności na członków korpusu urzędniczego zakaz publicznego manifestowania poglądów politycznych, uczestniczenia w strajku lub akcji protestacyjnej zakłócającej normalne funkcjonowanie urzędu, łączenia pracy w służbie cywilnej z mandatem radnego, tworzenia partii politycznych i uczestniczenia w nich, pełnienia funkcji w związkach zawodowych, kierowania się interesem jednostki lub grupowym podczas wykonywania obowiązków służbowych (art. 49). W służbie publicznej nie może po-

13 M. Droba, Podstawy prawa, Warszawa 2008, s. 166; Komunikat wiceprzewodniczącego Komisji Europejskiej, Neila Kinnocka w sprawie naboru urzędników z nowych państw członkowskich, przyjęty przez Komisję Europejską 18 lutego 2003 r., Bruksela 2003.

14 J. Czaputowicz, Stużba cywilna $w$ procesie integracji europejskiej, op. cit., s. 275-276; P. Tosiek, Komitologia. Szczególny rodzaj decydowania politycznego w Unii Europejskiej, Lublin 2007, s. 264-268; http://ombudsman.europa.eu/report07/pdf/pl/short07_pl.pdf, odczyt 2008. Sprawozdanie Europejskiego Rzecznika Praw Obywatelskich wskazuje - w 2007 r. podobnie jak w latach poprzednich, że większość dochodzeń (tj. 413, czyli 64\% łącznej liczby) dotyczyła Komisji Europejskiej. Natomiast 87 dochodzeń (14\% łącznej liczby) dotyczyło Europejskiego Urzędu Doboru Kadr (EPSO), 59 (9\%) - Parlamentu Europejskiego, 22 (3\%) - Europejskiego Urzędu ds. Zwalczania Nadużyć Finansowych, a 8 (1\%) - Rady Unii Europejskiej. Główne zarzuty dotyczące niewłaściwego administrowania to: brak przejrzystości, w tym odmowa udzielenia informacji (28\% spraw), niesprawiedliwe traktowanie lub nadużycie władzy (18\%), niezadowalający tryb postępowania (13\%), nieuzasadnione opóźnienie (9\%), dyskryminacja (8\%), zaniedbanie $(8 \%)$, pomyłki prawne $(4 \%)$ oraz niedopełnienie obowiązków, czyli niewypełnienie przez Komisję Europejską roli „strażnika traktatu" wobec państw członkowskich (3\%). Poza tym w raporcie Komisji Europejskiej, poprzedzającym przystąpienie Polski do UE podkreślono m.in. upolitycznienie urzędników w niektórych sektorach administracji, co uznane zostało za barierę dla stworzenia profesjonalnej służby cywilnej. Okazuje się, że zjawisko to też występuje wśród unijnych urzędników zaangażowanych w działania komitologiczne.

${ }_{15}$ Konstytucja RP z 2 kwietnia 1997 r., art. 153 ust. 1; Rozporządzenie w sprawie kadr urzędniczych Wspólnot Europejskich i rozporządzenie w sprawie warunków zatrudnienia innych pracowników Wspólnot Europejskich, Tytuł II, art. 11-26a. 
wstać również stosunek podległości służbowej pomiędzy małżonkiem oraz osobami pozostającymi ze sobą w stosunku pokrewieństwa (do drugiego stopnia) lub powinowactwa (pierwszego stopnia), oraz w stosunku przysposobienia, opieki lub kurateli (art. 50). Poza tym urzędnik nie może podejmować dodatkowego zatrudnienia czy zajęć zarobkowych bez pisemnej zgody dyrektora generalnego urzędu, ani wykonywać działań sprzecznych z obowiązkami wynikającymi z ustawy lub podważających zaufanie do służby cywilnej (art. 51).

Natomiast urzędnicy instytucji UE wykonują swoje obowiązki, kierując się interesem Wspólnot i nie mogą otrzymywać instrukcji/poleceń od jakiegokolwiek rządu, organizacji lub osób spoza ich instytucji. Poza tym bez zezwolenia organu mianującego urzędnikom nie wolno podejmować działalności zawodowej innego rodzaju na zewnątrz instytucji, w której są zatrudnieni, niezależnie od tego czy takie działania są wynagradzane, czy realizowane na zasadzie pro publico bono. Urzędnicy nie mogą również przyjąć od jakiegokolwiek rządu lub innej organizacji zewnętrznej żadnych tytułów, odznaczeń, prezentów lub korzyści pieniężnych, z wyjątkiem sytuacji, w których jest to związane z wykonywaną przez nich działalnością poprzedzającą ich mianowanie lub pozostaje w związku ze służbą wojskową czy innego rodzaju służbą w siłach zbrojnych. Mają również obowiązek powstrzymywania się od działań i wypowiedzi politycznych, które byłyby związane z zajmowanym przez nich stanowiskiem. Ponadto każda instytucja musi określić rodzaje zajęć bądź zatrudnienia, w stosunku do których wprowadza zakaz podejmowania ich przez urzędnika w okresie trzech lat od zakończenia służby, niezależnie od tego czy będzie otrzymywać za nie wynagrodzenie. Podobne ograniczenia mogą być zastosowane do współmałżonków urzędników. Warto też dodać, że większość służb cywilnych posiada regulacje różnego rodzaju konflikty interesów ${ }^{16}$.

Korpus służby cywilnej w Polsce składa się z pracowników służby cywilnej, czyli osób zatrudnionych na podstawie umowy o pracę oraz urzędników służby cywilnej, którzy zatrudnieni są na podstawie mianowania, po przeprowadzeniu postępowania kwalifikacyjnego i spełnieniu odpowiednich warunków (art. 3). Zgodnie z art. 22 ustawy o służbie cywilnej postępowanie kwalifikacyjne dla pracowników ubiegających się o mianowanie prowadzi Krajowa Szkoła Administracji Publicznej. W toku

16 A. Dębicka, M. Dębicki, M. Dmochowski, Prawo urzędnicze Unii Europejskiej, Warszawa 2004, s. 35-36. 
postępowania kwalifikacyjnego sprawdza się wiedzę, umiejętności i predyspozycje kierownicze niezbędne do wypełniania zadań służby cywilnej ${ }^{17}$. O uzyskanie mianowania w służbie cywilnej może ubiegać się osoba, która jest pracownikiem służby cywilnej, posiada tytuł magistra lub równorzędny, ma co najmniej 3-letni staż pracy w służbie cywilnej lub uzyskała zgodę dyrektora generalnego urzędu na przystapienie do postępowania kwalifikacyjnego przed upływem tego terminu - jednak nie wcześniej niż po upływie dwóch lat od nawiązania stosunku pracy w służbie cywilnej, zna co najmniej jeden język obcy spośród języków roboczych UE oraz jest żołnierzem rezerwy lub nie podlega powszechnemu obowiązkowi obrony (art. 19). Dyrektor generalny właściwego urzędu potwierdza również spełnienie następujących warunków u kandydata - obywatelstwo polskie, korzystanie z pełni praw publicznych, niekaralność za umyślne przestępstwo lub umyślne przestępstwo skarbowe. Pracownikiem służby cywilnej może zostać osoba będąca obywatelem polskim, korzystająca z pełni praw publicznych, nie karana za przestępstwo umyślne lub umyślne przestępstwo skarbowe, posiadająca wymagane kwalifikacje i ciesząca się nieposzlakowaną opinią (art. 4). Korpus służby cywilnej tworzą pracownicy zatrudnieni na stanowiskach urzędniczych średniego szczebla zarządzania, koordynujących, samodzielnych, specjalistycznych i wspomagających w: Kancelarii Prezesa Rady Ministrów, urzędach ministrów i przewodniczących komitetów wchodzących w skład Rady Ministrów oraz urzędach centralnych organów administracji rządowej; urzędach wojewódzkich oraz innych urzędach stanowiących aparat pomocniczych terenowych organów administracji rządowej podległych ministrom lub centralnym organom administracji rządowej; komendach, inspektoratach i innych jednostkach organizacyjnych stanowiących aparat pomocniczy kierowników zespolonych służb, inspekcji i straży wojewódzkich oraz kierowników powiatowych służb, inspekcji i straży - chyba że odrębne przepisy stanowią inaczej; Głównym Inspektoracie Inspekcji Handlowej, Urzędzie Rejestracji Produktów Leczniczych, Wyrobów Medycznych i Produktów Biobójczych, Biurze Nasiennictwa Leśnego oraz korpus służby cywilnej tworzą także - powiatowi i graniczni lekarze weterynarii

17 Rozporządzenie Prezesa Rady Ministrów z dnia 24 stycznia 2007 r. w sprawie sposobu przeprowadzenia postępowania kwalifikacyjnego w służbie cywilnej, Dz. U. Nr 13, poz. 82; Rozporządzenie Prezesa Rady Ministrów z dnia 27 grudnia 2007 r. zmieniające rozporządzenie w sprawie sposobu przeprowadzania postępowania kwalifikacyjnego w służbie cywilnej, Dz. U. Nr 249, poz. 1857. 
i ich zastępcy (art. 2). W każdym urzędzie utworzone zostało stanowisko dyrektora generalnego, który zapewnia funkcjonowanie i ciagłość pracy urzędu, warunki jego działania organizację pracy, dokonuje czynności z zakresu prawa pracy wobec osób zatrudnionych w urzędzie oraz sprawuje bezpośredni nadzór nad komórkami organizacyjnymi urzędu.

Urzędnikiem Unii Europejskiej jest osoba, która w jednej z instytucji unijnych wykonuje stałą pracę i została nominowana do jej wykonania na podstawie pisemnego aktu - umowy o pracę, wydanego przez tę instytu$\operatorname{cje}^{18}$. Osoby zatrudnione w ramach umowy o pracę w instytucjach UE zyskują status urzędnika służby cywilnej UE. Nie dotyczy to jednak kadry lokalnej w przedstawicielstwach Komisji, oddelegowanych ekspertów narodowych, specjalnych doradców do spraw kryzysów wewnętrznych oraz innych pracowników zatrudnionych za pośrednictwem firm zewnętrznych. Urzędnicy tworzą wyspecjalizowany korpus służby cywilnej, który pracuje dla poszczególnych instytucji oraz agencji wspólnotowych. Procedury związane z klasyfikacją, rekrutacją i awansem urzędników przedstawione zostały w Regulaminie Urzędniczym, na stronach EPSO i poszczególnych instytucji UE oraz internetowych zbiorach dokumentów $\mathrm{UE}^{19}$. Główne kategorie urzędników zostały w wyniku wdrażanej reformy administracyjnej od 2004 r. zredukowane z czterech (A, B, C, D) do dwóch grup (AD, AST), a nowa struktura kariery opiera się o szesnaście stopni. Asystenci (AST) zastępują urzędników kategorii C i B. Po rozpoczęciu kariery w stopniu od 1 do 4, asystenci mogą przekwalifikować się na końcowy stopień jedenasty. Administratorzy (AD) zastępujący istniejącą kategorię A są zatrudniani w stopniach od piątego do szesnastego. W przyszłości asystenci, którzy osiagnną dobrą ocenę pracy, po odbyciu odpowiedniego szkolenia i zaliczeniu egzaminów kwalifikacyjnych mogą objąć funkcję administratorów (tzw. procedura certyfikacji) ${ }^{20}$. W ten sposób system kariery będzie miał charakter linearny. Ponadto każdy ze stop-

18 M. Małecki, op. cit., s. 15.

$19 \mathrm{http}: / /$ europa.eu.int/epso/working/career/carehome_en.htm, odczyt 2008; http://europa.eu.int/comm/reform/2002/documents/staff_reform_2002_en.pdf, odczyt 2005; http://europa.eu.int/epso/working/workhome_en.htm, odczyt 2008; http://europa.eu.int/institutions/index_en.htm, odczyt 2008; http://europa.eu.int/institutions/ii_bodies/index_en.htm\#epso, odczyt 2008; http://europa.eu.int/comm/publications/booklets/eu_documentation/06/index_en.htm, odczyt 2008; http://europa.eu.int/comm/dgs/personnel_administration/statut/tocen100.pdf, odczyt 2008; http://europa.eu.int/comm/reform/2002/sheet1_en.htm, odczyt 2005.

20 http://ec.europa.eu/civil_service/job/official/index_pl.htm, odczyt 2008. 
ni dzieli się na pięć poziomów płacowych. Wyjątkiem od tej reguły jest jedynie najwyższy - szesnasty stopień zaszeregowania, który dzieli się na trzy poziomy. Każdy poziom w każdym stopniu jest kolejnym szczeblem kariery, któremu przypisana jest określona płaca. Klasyfikacja urzędników instytucji UE, a więc podział na stopnie i stanowiska przedstawia aneks 13 Regulaminu Urzędniczego ${ }^{21}$. Z kolei o podziale stanowisk w polskiej służbie cywilnej traktuje rozporządzenie Prezesa Rady Ministra z 2007 roku $^{22}$. W polskim systemie administracji podjęto próbę wprowadzenia klasyfikacji urzędników (A, B, S, C), ta jednak nie sprawdziła się i nowe rozwiązania administracyjne odbiegają od takiego ujęcia ${ }^{23}$.

Kandydatów do zatrudnienia w polskiej służbie cywilnej wyłania się w drodze naboru na wolne stanowiska pracy. Wyższe stanowiska w służbie cywilnej, czyli stanowiska dyrektorskie były zgodnie z ustawą z $1998 \mathrm{r}$. obsadzane w drodze konkursu. Do momentu wprowadzenia zasobu kadrowego w 2006 r. wyższe stanowiska w służbie cywilnej (dyrektorzy generalni urzędów, dyrektorzy departamentów lub wydziałów i ich zastępcy), obsadzane były w drodze konkursu, organizowane przez Szefa Służby Cywilnej. Konkursy miały zapewnić profesjonalizm i neutralność polityczną dyrektorów administracji publicznej. Od kandydatów wymagano wiedzy do wykonywania zadań na danym stanowisku, odpowiednich predyspozycji, zdolności ogólnych i menedżerskich. Ustawą z sierpnia 2006 roku nie tylko zrezygnowano z konkursów, ale też zlikwidowano stanowisko Szefa Służby Cywilnej, Urząd Służby Cywilnej i Radę Służby Cywilnej.

Nabór do służby cywilnej prowadzony jest w sposób zdecentralizowany i należy do poszczególnych urzędów. Metody wyłaniania kandydatów na wolne stanowisko są autonomiczną decyzją dyrektorów generalnych. Dyrektor generalny musi jednak zagwarantować otwartość i konkurencyj-

21 http://ec.europa.eu/civil_service/docs/toc100_en.pdf, odczyt 2008.

22 Rozporządzenie Prezesa Rady Ministrów z dnia 16 stycznia 2007 r. w sprawie określenia stanowisk urzędniczych, wymaganych kwalifikacji zawodowych, stopni służbowych urzędników służby cywilnej, mnożników do ustalania wynagrodzenia oraz szczegółowych zasad ustalania i wypłacania innych świadczeń przysługujących członkom korpusu służby cywilnej, Dz. U. Nr 12, poz. 79.

23 W. Jednaka, Proces decyzyjny w administracji rzqdowej, w: Administracja i Polityka. Proces decyzyjny $w$ administracji publicznej, pod red. L. Habudy, Wrocław 2000, s. 118-119. Kategorie urzędnicze były wprowadzone ustawą z dnia 5 lipca 1996 r. o służbie cywilnej, a zostały zniesione z dniem 1 lipca 1999 roku, a więc wprowadzeniem w życie ustawy o służbie cywilnej z 18 grudnia 1998 roku. 
ność naboru oraz opublikować informację o wolnym stanowisku w miejscu ogólnodostępnym na terenie urzędu oraz w „Biuletynie Informacji Publicznej Kancelarii Prezesa Rady Ministrów" (przed nowelizacją z 2006 r. w „Biuletynie Służby Cywilnej”). Dyrektor generalny urzędu organizuje nabór kandydatów do korpusu służby cywilnej, a dotyczy to także absolwentów Krajowej Szkoły Administracji Publicznej.

Rekrutacja do służby cywilnej w instytucjach UE odbywa się również na zasadzie otwartości (jawności), konkurencyjności oraz warunków wstępnych i procedur. Warunki podstawowe naboru w instytucjach UE zawierają - obywatelstwo jednego z państw członkowskich UE (wyjątek stanowią tzw. kandydaci zewnętrzni na funkcje dyrektorów i dyrektorów generalnych), pełne prawa obywatelskie, uregulowany stosunek do służby wojskowej i znajomość przynajmniej jednego języka oficjalnego UE poza językiem ojczystym. Z kolei warunki szczególne obejmują wymagania związane z przyszłymi obowiązkami zawodowymi i są one każdorazowo wyszczególniane w zawiadomieniu o konkursie ${ }^{24}$.

Rekrutacja przyszłych urzędników w instytucjach UE zwykle odbywa się w drodze konkursu, z wyjątkiem urzędników stopnia AD 16-15 (do 2004 r. i w okresie przejściowym - A1 i A2 ), którzy na swoje stanowiska są mianowani. W lipcu 2002 r. zostało powołane Europejskie Biuro Selekcji Kadr (EPSO) dla instytucji UE. Zajmuje się ono rekrutacją stałych pracowników do Komisji Europejskiej, Parlamentu Europejskiego, Komitetu Ekonomiczno-Społecznego, Komitetu Regionów, Europejskiego Trybunału Sprawiedliwości oraz Biura Rzecznika Praw Obywatelskich. Proces rekrutacji składa się z czterech etapów: 1) wypełnienie formularza rejestracyjnego; 2) testy preselekcyjne; 3) egzamin pisemny; 4) rozmowa kwalifikacyjna. Po wpisaniu na listę rezerwową kandydatów - jak wskazuje praktyka - ważna jest własna inicjatywa kandydata i lobbing ${ }^{25}$. Dyrektorzy Generalni i dyrektorzy przed nominacją na stanowisko kierownicze, podlegają procedurze rekrutacji, w której uczestniczą - Komitet Konsultacyjny ds. Nominacji, Komisarz ds. Rekrutacji, Personelu i Administracji oraz Przewodniczący Komisji Europejskiej. Głównym zadaniem Komitetu Konsultacyjny ds. Nominacji jest doradzanie Kolegium w sprawach rekrutacji na stanowiska AD 15-16. Komitet Konsultacyjny ds. Nominacji

24 Ł. Dzienisz, J. Sobieska, Praca i staże w Unii Europejskiej, Warszawa 2004, s. 97.

25 Ł. Dzienisz, J. Sobieska, Praca i staże w Unii Europejskiej, Warszawa 2004, s. 104 . 
działa też jako organ oceniający kandydatów i przeprowadzający z nimi rozmowy. Dokonuje wstępnej selekcji kandydatów spełniających kryteria. Po przesłuchaniu kandydatów Komitet Konsultacyjny ds. Nominacji przyjmuje opinię większością głosów lub za porozumieniem i na jej podstawie sporządza skróconą listę kandydatów. Obrady Komitetu są poufne. Natomiast skrócenie listy następuje na podstawie - kompetencji, zdolności interpersonalnych i zdolności menedżerskich. Następnie lista przesyłana jest Komisarzowi ds. Rekrutacji, który decyduje o tym czy lista skrócona jest właściwa, zaprasza kandydatów na dodatkowe rozmowy i przygotowuje propozycję ostatecznej decyzji, podejmowanej przez Komisję. Komisja podejmuje decyzję na podstawie propozycji Komisarza ds. Rekrutacji oraz ds. Personelu i Administracji. Może jednak okazać się, że brak jest satysfakcjonujących kandydatów, w wyniku czego, Komisarz ds. Personelu oraz Przewodniczący KE mogą przesłuchać dodatkowych kandydatów, którzy nie znaleźli się na skróconej liście lub decydują o ponownej publikacji informacji o wakatach $^{26}$.

Pracownik podejmujący po raz pierwszy pracę w polskiej administracji publicznej zobowiązany jest do odbycia służby przygotowawczej, a w trakcie wykonywania pracy - szkolen ${ }^{27}$. Podobnie w instytucjach UE mamy do czynienia z okresem próbnym i szkoleniami ${ }^{28}$. Służba przygotowawcza przygotowuje teoretycznie i praktycznie do pracy w administracji publicznej, a kończy się egzaminem - jeżeli z pomyślną notą, to urzędnik otrzymuje umowę na czas nieokreślony. W trakcie służby przygotowawczej pracownik zdobywa wiedzę z zakresu swojego urzędu i stanowiska pracy.

Służba cywilna w Polsce, jak i w instytucjach UE podlega ocenie, która w obu przypadkach nie tylko rozlicza urzędnika z wykonywanych obowiązków, ale jest również po to, aby go wspierać, rozwijać i motywować. Bezpośredni przełożony nie rzadziej niż raz na dwa lata i nie częściej niż raz na rok bezpośredni przełożony sporządza na piśmie okresową ocenę urzędnika służby cywilnej, wraz z wnioskami dotyczącymi jego indywidualnego programu rozwoju zawodowego. Jest ona sporządzana na podstawie kryteriów obowiązkowych i kryteriów wybranych przez bezpośredniego przełożonego (wykaz kryteriów zawiera załącznik nr 1 do rozporządze-

26 http://europa.eu.int/comm/reform/2002/sheet1_en.htm, odczyt 2005.

27 Rozporządzenie Prezesa Rady Ministrów z dnia 25 kwietnia 2007 r. w sprawie szkoleń w służbie cywilnej, Dz. U. 2007, Nr 76, poz. 507.

28 http://ec.europa.eu/civil_service/admin/perform/index_pl.htm, odczyt 2008. 
nia) i zapisana jest w tzw. arkuszu okresowej oceny urzędnika służby cywilnej $^{29}$. Oceniający przed sporządzeniem oceny na piśmie przeprowadza z ocenianym rozmowę podczas której omawia $\mathrm{z}$ nim główne obowiązki $\mathrm{i}$ ich realizację, trudności napotykane przez ocenianego $\mathrm{w}$ trakcie realizacji zadań oraz kierunki dalszego rozwoju i potrzeby szkoleniowe ocenianego. Od oceny służy w ciagu siedmiu dni od dnia doręczenia oceny urzędnikowi - sprzeciw do dyrektora generalnego, który jest rozpatrywany w ciagu 14 dni od dnia jego doręczenia. W przypadku uwzględnienia sprzeciwu ocenę okresową zmienia się albo sporządza po raz drugi. Ostatecznie urzędnik może odwołać się do sądu pracy (art. 53, ust. 4). Rezultatem oceny okresowej, zgodnie z przepisami ustawy o służbie cywilnej mogą być następujące rozwiązania - rozwiązanie stosunku pracy urzędnika służby cywilnej w razie dwukrotnej, następującej po sobie, negatywnej oceny (art. 41, ust. 1, pkt 1); otrzymanie przez urzędnika służby cywilnej kolejnego stopnia służbowego po uzyskaniu pozytywnej oceny na wniosek bezpośredniego przełożonego (art. 59, ust.1); obligatoryjne przyznanie kolejnego stopnia służbowego po uzyskaniu drugiej pozytywnej oceny na najwyższym poziomie, od otrzymania ostatniego stopnia służbowego (art. 59, ust. 2) oraz ustalanie przez dyrektora generalnego urzędu indywidualnego programu rozwoju zawodowego urzędnika służby cywilnej, po uwzględnieniu m.in. oceny pracy urzędnika (art. 75). Decyzję o przyznaniu urzędnikowi kolejnego stopnia służbowego podejmuje dyrektor generalny urzędu (odnośnie art. 59, ust. 1). Natomiast otrzymanie przez urzędnika służby cywilnej kolejnego stopnia nie następuje z mocy prawa w dniu spełnienia wymogów jego otrzymania. Niezbędne jest również oświadczenie woli dyrektora generalnego urzędu o przyznaniu kolejnego stopnia służbowego. Przepisy ustawy o służbie cywilnej nie wskazują terminu, w którym takie oświadczenie powinno być złożone, jednak w opinii Kancelarii Premiera Rady Ministrów - powinno to nastąpić niezwłocznie po uzyskaniu przez pracodawcę informacji o spełnieniu przez urzędnika służby cywilnej warunków uzyskania kolejnego stopnia służbowego określonych w art. 59, ust. 2 ustawy $^{30}$.

W instytucjach UE, reformą z 2004 r. wprowadzono nowy system oceny pracownika, który zniósł automatyczny awans na wyższy stopień.

29 Rozporządzenie Prezesa Rady Ministrów z dnia 5 kwietnia 2007 r. w sprawie szczegółowych zasad przeprowadzania ocen urzędników służby cywilnej, Dz. U. z 2007 r. Nr 69, poz. 453.

$30 \mathrm{http}: / /$ www.dsc.kprm.gov.pl/strona.php?id=126\&id2=21, odczyt 2008. 
Odtąd rozwój kariery urzędnika jest uzależniony od ilości przyznanych punktów merytorycznych w procedurze oceny i punktów priorytetowych w procedurze promocji. Punkty te są wynikiem jakości pracy i są zapisywane w Formularzu Rozwoju Kariery, odrębnym dla każdego urzędnika. Stąd promocja na wyższy stopień nie zależy od czasu wykonywanej pracy i wieku urzędnika. Coroczna ocena urzędników (aż do stopnia AD14) bazuje na punktach merytorycznych. Urzędnicy zmieniający stanowisko pracy na nowe zabierają ze sobą zdobyte dotychczas punkty. Kluczowymi wskaźnikami branymi pod uwagę są - wykonywanie pracy (efekty pracy), umiejętności (zdolności) i ogólna postawa. W tej procedurze można otrzymać maksymalnie 20 punktów merytorycznych (maksymalnie - 10 punktów za wykonanie pracy, 6 punktów za umiejętności i 4 punkty za ogólną postawę). Punkty priorytetowe przyznawane są w procedurze promocji, która zaczyna się na początku kwietnia każdego roku po zakończeniu procesu oceny. Dyrektor Generalny może przyznać do 10 punktów za specjalne zasługi Dyrektoriatowi Generalnemu. I w ramach Dyrektoriatu Generalnego połowę tych punktów uzyskuje 15\% urzędników, tych, którzy są ocenieni powyżej średniej. Druga połowa punktów przyznawana jest pozostałym urzędnikom. Dodatkowe dwa punkty priorytetowe moga być przyznane przez Komitety ds. Promocji - działające w ramach każdego Dyrektoriatu Generalnego. Komitet ds. Promocji bierze pod uwage działania wykonywane w interesie Komisji, czyli uznanie za działanie na rzecz całej instytucji. Maksymalna liczba punktów uzyskana w procesie oceny i promocji sięga 32. Szczególną uwagę zwraca się na ocenę i promocję urzędników na stanowiskach zarządzających. Jeśli szefowie wydziałów zostaną w sposób niesatysfakcjonujący ocenieni w dwóch kolejnych raportach, to podlegają dodatkowej ocenie jednego z dwudziestu wyższej rangi urzędników, zajmujących się przygotowaniem raportów pracowniczych. W przypadku, gdy urzędnik kierujący raportem zgodzi się z wynikiem poprzednich negatywnych raportów, to może skierować sprawę do Komitetu Konsultacyjnego ds. Nominacji (CCA), który zaopiniuje czy przenieść szefa wydziału na inne stanowisko zarządzające, czy też przenieść na stanowisko nie znajdujące się w pionie zarządzania. Natomiast odrębny system oceny został wprowadzony dla nowo powołanych szefów wydziałów, pracujących w okresie próbnym. Po pięciu miesiącach poddani zostaną nieformalnej ocenie, a pod koniec okresu próbnego ostatecznej ocenie formalnej. Natomiast każdy z wyższych urzędników (Dyrektor Generalny, Dyrektor) poddany jest pełnej ocenie przynajmniej raz na dwa lata. Ocena zawiera: samoocenę, rozmowę z bezpośrednim przełożonym, 
który formułuję ocenę na podstawie opinii pracowników. Przewiduje się procedurę apelacyjną $\mathrm{w}$ związku $\mathrm{z}$ raportem na temat wykonywanych obowiązków. Rezultatem oceny są decyzje w sprawie promocji lub mobilności pracownika. Natomiast nowi wyżsi urzędnicy poddani są pisemnej ocenie dopiero po roku od objęcia stanowiska. W przypadku negatywnej oceny wskazuje się problemy i wspólnie z urzędnikiem opracowuje się plan ich rozwiązywania. A jeśli taki plan nie przyniesie pozytywnych efektów, wówczas stosuje się: przeniesienie na inne stanowisko bądź przeniesienie na niższy stopień bądź urzędnik zostaje odesłany na wcześniejszą emeryturę. Z kolei zewnętrzni kandydaci, zatrudnieni w okresie próbnym przez rok, a przed upływem tego okresu odbywają rozmowę z Komisarzem lub Dyrektorem Generalnym na temat pełnienia przez nich obowiązków. Ocena wydana jest pod koniec okresu próbnego, a jeśli jest negatywna to wiąże się z zakończeniem pracy, a więc nieprzedłużeniem umowy ${ }^{31}$.

Służba cywilna wykonuje swoją pracę w oparciu o opisy stanowisk pracy, tworzone zarówno w Polsce, jak i w instytucjach Unii Europejskiej. Opisy stanowisk pracy w polskiej służbie cywilnej, jak wskazuje ustawa o służbie cywilnej - są wykorzystywane w różnych elementach procesu zarządzania kadrami - dla celów rekrutacji, w procesie oceny urzędnika, wartościowaniu stanowisk pracy, wskazują miejsce stanowiska w organizacji oraz wpływ stanowiska na efekt końcowy zadania, także dla projektowania nowych stanowisk i zmodyfikowania obecnych, w sporządzeniu zakresu obowiązków pracownika, planowaniu rozwoju zawodowego pracownika, wspomagają też proces zarządzania wynagrodzeniami w organizacji, a także sprzyjają pogrupowaniu stanowisk ${ }^{32}$. Podobnie jest $w$ instytucjach Unii Europejskiej - w procesie oceny i promocji przydatne dla urzędnika są opisy stanowisk pracy tworzone od 2002 r. przez tzw. menadżerów liniowych (posady związane z zarządzaniem w ramach Dyrektoriatu Generalnego). Opisy stanowisk pracy są częścią dokumentu - Strategicznego Planowania i Programowania (SPP). Składają się one z trzech stałych punktów - profilu pracy (obowiązki pracownika), środowiska pracy (czynniki wpływające na warunki pracy) i wymagań stanowiska pracy (elementy uznane za niezbędne do właściwego wykonywania pracy, np. szkolenie, edukacja i doświadczenie). Warto nadmienić, że w ramach regulacji odnośnie administracji powstała tzw. Grupa sterująca ds. zarządzania kosztami

31 http://europa.eu.in/index_pl.htm; http://europa.eu.int/comm/reform/2002/index2_en.htm, odczyt 2005.

${ }^{32}{ }^{-}$http://www.dsc.kprm.gov.pl/strona.php?id=114, odczyt 2008. 
działań, której przewodniczy Sekretarz Generalny i dyrektorzy gabinetów odpowiadający za służby centralne. Grupa ta koordynuje zagadnienia strategiczne dotyczące instrumentów horyzontalnych, takich jak planowanie i programowanie strategiczne oraz kontrola wewnętrzna, oraz regularnie bada stosowanie procedur wewnętrznych Komisji ${ }^{33}$.

Zwierzchnikiem korpusu służby cywilnej w Polsce jest Prezes Rady Ministrów. Sprawuje on nadzór nad służbą cywilną i może wydawać zarządzeniem wytyczne i polecenia w zakresie przestrzegania zasad służby cywilnej. Natomiast Szef Kancelarii Prezesa Rady Ministrów wykonuje z upoważnienia Prezesa RM zadania z zakresu służby cywilnej (w miejsce zlikwidowanego: Urzędu Służby Cywilnej). Odpowiada zatem za bieżącą działalność, w tym również za organizowanie szkoleń. Organem opiniodawczo-doradczym, oceniającym przebieg postępowań kwalifikacyjnych, egzaminacyjnych jest Rada Służby Cywilnej. Z kolei do rozpoznania spraw dyscyplinarnych członków korpusu służby cywilnej została powołana Wyższa Komisja Dyscyplinarna i komisje dyscyplinarne. Poza tym zgodnie z art. 84, ust. 1 ustawy o służbie cywilnej - Szef Kancelarii Prezesa Rady Ministrów tworzy po jednej komisji dyscyplinarnej dla co najmniej trzech urzędów. Komisję dyscyplinarną, w liczbie co najmniej 10 członków korpusu służby cywilnej, powołuje się na okres 3 lat. Szef Kancelarii Prezesa Rady Ministrów powołuje członków korpusu służby cywilnej posiadających wyższe wykształcenie, doświadczenie zawodowe odpowiednie do merytorycznego zakresu działania urzędów, dla których została utworzona komisja dyscyplinarna, także którzy wyrazili pisemną zgodę na wykonywanie zadań w komisji ${ }^{34}$. W skład komisji dyscyplinarnej powinny wchodzić co najmniej dwie osoby posiadające wyższe wykształcenie prawnicze, z których co najmniej jedna powinna być urzędnikiem służby cywilnej. W składzie komisji nie może być powołany członek korpusu służby cywilnej, który jest członkiem innej komisji dyscyplinarnej, wykonuje zadania w Wyższej Komisji Dyscyplinarnej lub pełni funkcję rzecznika dyscyplinarnego ${ }^{35}$. Ponadto na czas wykonywania

33 http://ec.europa.eu/atwork/synthesis/doc/governance_statement_20070530_pl.pdf, odczyt 2008.

34 Art. 2 rozporządzenia Prezesa Rady Ministrów z dnia 21 grudnia 2006 r. w sprawie postępowania wyjaśniającego i postępowania dyscyplinarnego w służbie cywilnej, Dz. U. Nr 246, poz. 1798.

35 Art. 7 rozporządzenia Prezesa Rady Ministrów z dnia 21 grudnia 2006 r. w sprawie postępowania wyjaśniającego i postępowania dyscyplinarnego w służbie cywilnej, Dz. U. Nr 246, poz. 1798. 
zadań w komisjach dyscyplinarnych jej członkom przysługuje zwolnienie od pracy zawodowej (art. 86), identycznie jest w przypadku członków unijnej Rady Dyscyplinarnej. Członkowie komisji dyscyplinarnych są niezawiśli w zakresie orzecznictwa dyscyplinarnego i są związani jedynie prawomocnym wyrokiem sądu. Członek korpusu służby cywilnej odpowiada dyscyplinarnie za naruszenie swoich obowiązków. W konsekwencji może on otrzymać następujące kary: upomnienie, naganę, obniżenie wynagrodzenia zasadniczego, nie więcej niż o $25 \%$ przez okres nie dłuższy niż sześć miesięcy (art. 81). Dodatkowo urzędnika służby cywilnej może spotkać - pozbawienie możliwości awansowania przez okres dwóch lat na wyższy stopień służbowy, obniżenie stopnia służbowego służby cywilnej czy wydalenie ze służby cywilnej (prawomocne orzeczenie skutkuje zakazem pięcioletnim ubiegania się o pracę w korpusie służby cywilnej), a pracownika służby cywilnej - wydalenie z pracy w urzędzie (prawomocne orzeczenie kary powoduje wygaśnięcie stosunku pracy i pięcioletni zakaz ubiegania się o zatrudnienie w korpusie służby cywilnej). Komisja dyscyplinarna wszczyna postępowanie dyscyplinarne $\mathrm{z}$ dniem zgłoszenia wniosku rzecznika dyscyplinarnego o wszczęcie postępowania (art. 92). Obwiniony ma prawo do obrońcy, z zastrzeżeniem przepisów o ochronie tajemnicy ustawowo chronionej. Komisja dyscyplinarna wydaje orzeczenie po przeprowadzeniu rozprawy (wysłuchuje rzecznika dyscyplinarnego, obwinionego i jego obrońcy, a także rozpatruje inne dowody). Rozprawa jest jawna (choć skład orzekający może wyłączyć jawność rozprawy) i orzeczenie. Od orzeczenia komisji dyscyplinarnej strony mogą odwołać się do Wyższej Komisji Dyscyplinarnej.

W administracji instytucji UE również występuje hierarchiczny porządek (na wzór ministerstw), czego wyraźnym przykładem są Dyrektoriaty Generalne w Komisji Europejskiej, na czele których stoi dyrektor generalny, urzędnik służb cywilnych. Nadzór nad Dyrektoriatem pełni określony komisarz. W praktyce Dyrektoriaty Generalne są koordynowane przez gabinety tworzone przy każdym komisarzu i prezydencie, a z drugiej strony przez Sekretariat Generalny ${ }^{36}$. Natomiast procedury dyscyplinarne i inne działania kontrolne - podobnie jak system oceny urzędnika, ujęte są w Regulaminie Urzędniczym i na archiwalnych stronach serwera

36 R. Herbut, Proces podejmowania decyzji w Unii Europejskiej - rola Komisji Europejskiej, w: Administracja i polityka. Proces decyzyjny w administracji publicznej, pod red. L. Habudy, Wrocław 2000, s. 105. 
„Europa” ${ }^{\text {37 }}$. Procedury dyscyplinarne odnoszą się zwykle do poważnych naruszeń, w szczególności - korupcji, oszustwa i przestępstw karanych zgodnie z prawem narodowym. System odpowiedzialności dyscyplinarnej stosowany jest również w przypadku niedopełnienia, poprzez celowe działanie lub zaniedbanie obowiązków ustanowionych w Regulaminie Urzędniczym $^{38}$. Zgodnie z reformą administracyjną z 2004 r. Rada Dyscyplinarna działa na bieżąco w określonym składzie. Członkami Rady są - czterech urzędników stopnia AD14, a dla wyższych urzędników dwóch dodatkowych członków z tym samym stopniem lub co najmniej z tego samego poziomu co urzędnik stojący przed Radą. Przewodniczący Rady wybierany jest na pięcioletnią kadencję i pełni swoją funkcję jako członek niezależny. Obrady Rady i dokumenty są tajne. Istotną kompetencją Rady jest możliwość na wniosek swoich członków - wznowienia dochodzenia. Reforma wprowadziła również dwa różne odrębne wstępne śledztwa i organy do ich prowadzenia, ale tylko jedna instytucja, tj. Biuro Dochodzeń i Dyscypliny Komisji albo Europejski Urząd ds. Zwalczania Nadużyć Finansowych (OLAF) będą zajmować się jedną sprawą ${ }^{39}$. Przy czym - OLAF będzie zajmować się przestępstwami w sprawach o dużej wadze, np. korupcji, defraudacji, a Biuro Dochodzeniowe i Dyscypliny - negatywnym postępowaniem urzędników, naruszającym wewnętrzne przepisy np. Regulamin Urzędniczy. Warto jednak podkreślić, że oba organy dokonują jedynie prac dochodzeniowych, podczas gdy wiążące środki dyscyplinarne mogą być przedsięwzięte jedynie przez „Organ Wyznaczający” (por. Regulamin Urzędniczy) po złożeniu sprawozdania przez OLAF lub IDOC $^{40}$. Ze wstępnego dochodzenia sporządzany jest raport, który zawiera ocenę prowadzenia wstępnego badania, opis stanu faktycznego i kwe-

$37 \mathrm{http}: / /$ europa.eu.int/comm/dgs/personnel_administration/working_en.htm, odczyt 2008; http://europa.eu.int/comm/dgs/personnel_administration/statut/tocen100.pdf, odczyt 2008; http://europa.eu.int/comm/reform/2002/chapter05_en.htm\#3, odczyt 2005; http://europa.eu.int/comm/reform/2002/conduct_chapter7_en.html\#7_3, odczyt 2005; http://europa.eu.int/comm/reform/2002/code_conduct_en.htm, odczyt 2005.

$38 \mathrm{http}: / /$ ec.europa.eu/atwork/synthesis/doc/governance_statement_20070530_pl.pdf, odczyt 2008.

${ }^{39} \mathrm{http}: / /$ europa.eu.int/comm/reform/2002/conduct_chapter7_en.html\#7_3, odczyt 2005.

${ }^{40} \mathrm{http}: / /$ www.europarl.eu.int/comparl/cont/site/auditions/commissaires/replies pl.pdf, odczyt 2005; http://eur-lex.europa.eu/LexUriServ/LexUriServ.do?uri=OJ:C:2008: 033:0002:01:PL:HTML, odczyt 2008. 
stie prawne oraz polecenie zastosowania środków dyscyplinarnych. $\mathrm{Na}$ podstawie raportu oraz po wysłuchaniu urzędnika, którego dotyczy dochodzenie - Komisja może podjąć trzy kierunki działania. Po pierwsze podjąć decyzję o niepodejmowaniu żadnych działań, po drugie - skierować pisemne ostrzeżenie lub naganę, a po trzecie - rozpocząć postępowanie dyscyplinarne przed Radą Dyscyplinarną. W postępowaniu przed Radą Dyscyplinarną urzędnik ma prawo do obrońcy wybranego przez siebie. W ramach Rady, ostateczna decyzja odnośnie środków dyscyplinarnych podejmowana jest przez grupę najwyższych rangą urzędników o nazwie „Senior”.

Służba cywilna w Polsce posiada państwową jednostkę organizacyjna, przygotowującą do służby cywilnej, a jest nią Krajowa Szkoła Administracji Publicznej. Placówka ta zajmuje się kształceniem kadr (status szkoły wyższej), prowadzeniem postępowań kwalifikacyjnych dla pracowników służby cywilnej, ubiegających się o mianowanie, także przeprowadzenia egzaminów do państwowego zasobu kadrowego. Adepci szkoły, po zakończeniu nauki zmuszeni są do pięcioletniej pracy w administracji publicznej, w związku z czym otrzymują z pominięciem służby przygotowawczej, mianowanie na urzędnika Służby Cywilnej. Warto też zwrócić uwagę, iż istnieje również tzw. „państwowy zasób kadrowy”. Stanowi on zbiór kandydatów na wysokie stanowiska państwowe, określone ustawą, m.in. kierownicy centralnych urzędów administracji, prezesi agencji państwowych i ich zastępcy, prezesi zarządów państwowych funduszy i ich zastępcy, dyrektorzy generalni urzędów, kierujący departamentami w ministerstwach i urzędach centralnych. Państwowy zasób kadrowy tworzą m.in. urzędnicy służby cywilnej (w okresie 10 lat od dnia wejścia do zasobu, po upływie tego okresu konieczne jest złożenie egzaminu z wynikiem pozytywnym); osoby, które złożą z wynikiem pozytywnym egzamin (przeprowadza Krajowa Szkoła Administracji Publicznej); osoby, które wygrają konkurs ogłoszony przez Prezesa Rady Ministrów, rozpisany w sytuacji, gdy poszukuje się osób ze szczególnym doświadczeniem lub umiejętnościami zawodowymi, wymaganymi do pracy na stanowisku obsadzanym z państwowego zasobu kadrowego; osoby mianowane przez Prezydenta Rzeczpospolitej Polskiej na pełnomocnych przedstawicieli Rzeczpospolitej Polskiej w innych państwach i przy organizacjach międzynarodowych oraz osoby posiadające stopień naukowy doktora.

Warto też nadmienić o zmianach, jakie czekają służbę cywilną w związku z przegłosowaniem w Sejmie projektu nowelizacji ustawy 
o służbie cywilnej, dnia 24 października 2008 roku$^{41}$. Ustawa zakłada likwidację Państwowego Zasobu Kadrowego powołanego w 2006 r. i włączenie wyższych stanowisk w administracji państwowej do służby cywilnej $^{42}$. Zgodnie z projektem stanowiska będą obsadzane w drodze naboru otwartego i konkursów - a takie rozwiązanie przybliży Polskę do standardów zatrudnienia w administracjach krajów europejskich. W ustawach regulujących zasady funkcjonowania poszczególnych instytucji wprowadzono minimalne wymagania stawiane kandydatom na ich szefów. Dotyczyć ma to m.in. dyrektorów generalnych urzędów oraz dyrektorów departamentów i ich zastępców ${ }^{43}$. Członkowie korpusu służby cywilnej, posiadający odpowiednie kwalifikacje oraz przygotowanie zawodowe będą mogli w drodze awansu wewnętrznego obejmować wyższe stanowiska (z wyjątkiem dyrektora generalnego urzędu). Nabór na wyższe stanowiska jest kierowany do osób posiadających stopień magistra (lub równorzędny), co najmniej trzyletni staż pracy w jednostkach sektora finansów publicznych, w tym rok na stanowisku kierowniczym lub samodzielnym. Odnośnie dyrektora generalnego - sześcioletni staż pracy, w tym trzy lata na stanowisku kierowniczym. Ogłoszenia o wolnych stanowiskach pracy oraz informacje o wynikach naboru mają być zamieszczane na stronach Biuletynu Informacji Publicznej Kancelarii Premiera i BiP urzędu poszukującego pracownika. Założono możliwość zatrudniania w służbie cywilnej osób, które nie posiadają obywatelstwa polskiego, ale mają obywatelstwo państwa należącego do Unii Europejskiej lub innego kraju, z którym Polska podpisała umowę międzynarodową. Osobę taką będzie można zatrudnić na stanowiskach wskazanych przez dyrektora generalnego urzędu, jeśli oprócz kierowniczych kwalifikacji, będzie dysponowała dokumentem świadczącym o znajomości języka polskiego. Projekt nowelizacji tworzy także możliwość obejmowania wyższych stanowisk, z wyjątkiem dyrektora generalnego urzędu - w drodze awansu wewnętrznego, a warunkiem ma być posiadanie odpowiednich kwalifika-

41 http://wiadomości.onet.pl/1850238,11,1,,item.html, odczyt 2008; http://www.kprm.gov.pl/s.php?doc=1373, odczyt 2008.

42 Zniesienie ustawy z 24 sierpnia 2006 r. o Państwowym Zasobie Kadrowym (Dz. U. Nr 170, poz. 1217 ze zm.) oznacza, że prawie 40 prezesów agencji funduszy i szefów urzędów centralnych nie będzie już powoływanych spośród członków PZK.

${ }^{43}$ Zgodnie z projektem stanowisko dyrektora generalnego urzędu będzie tworzone w tych urzędach, w których przewidywała to ustawa o PZK. W projekcie wskazano urzędy, w których te stanowiska nie będą funkcjonowały. Są to komendy główne - Policji, Straży Granicznej i Państwowej Straży Pożarnej. 
cji i przygotowanie zawodowe. Wyższe stanowiska w służbie cywilnej mają być apolityczne (zakaz publicznego manifestowania swoich poglądów, łączenia pracy w służbie cywilnej z mandatem radnego, uczestniczenia w strajkach, tworzeniu partii politycznych i uczestnictwa w nich, a także zakaz pełnienia funkcji w związkach zawodowych). Nabór na wyższe stanowisko w służbie cywilnej ma przeprowadzać zespół członków korpusu służby cywilnej, liczący od trzech do pięciu osób. Zespół ten wyłoni maksymalnie dwóch kandydatów, których przedstawi do wyboru właściwemu ministrowi, bądź kierownikowi odpowiedniego urzędu. Z naboru sporządzany jest protokół, zawierający informacje m.in. o stanowisku oferowanym, a także uzasadnienie dokonanego wyboru. Zgodnie z ustawą kariera urzędnika ma zależeć od ocen okresowych. Podobnie jak w instytucjach Unii Europejskiej, systemem ocen okresowych mają być objęci wszyscy członkowie korpusu służby cywilnej - w tym dyrektorzy generalni urzędów, dyrektorzy komórek organizacyjnych i ich zastępcy. Poza tym stanowiska stracą osoby, które weszły do Państwowego Zasobu Kadrowego i powierzono im stanowiska kierownicze w administracji, pomimo iż nie spełniali wymogów dotyczących stażu pracy. Wyższych stanowisk nie będą mogły również pełnić osoby, które nie posiadają pięcioletniego stażu pracy lub nie zdały egzaminu do PZK lub nie wygrały konkursu ogłoszonego przez Prezesa Rady Ministrów. Nowelizacja przewiduje również powołanie szefa Służby Cywilnej. Stanowisko to będzie należeć do osoby spełniającej określone wymagania, np. w momencie powołania nie jest członkiem partii i również nie była nim w ostatnich pięciu latach. Poza tym taki kandydat musi posiadać wiedzę na temat organizacji i funkcjonowania administracji publicznej, popartą doświadczeniem na stanowiskach kierowniczych. Szef Służby Cywilnej będzie podlegał bezpośrednio premierowi. Szefa Służby Cywilnej będzie można odwołać w określonych sytuacjach - m.in. w przypadku złożenia rezygnacji lub niewypełnienia obowiązków z powodu długotrwałej choroby lub utraty „nieposzlakowanej opinii”. Głównym zadaniem Szefa Służby Cywilnej będzie opracowanie projektu strategii zarządzania kadrami w służbie cywilnej. Kolejną zmianą jest powołanie przez premiera w miejsce obecnej Rady Służby Publicznej - piętnastoosobowej Rady Służby Cywilnej. Premier powoła ośmiu (ekspertów) z piętnastu jej członków, a pozostali członkowie będą reprezentować wszystkie kluby parlamentarne (7 osób). Zadaniem Rady Służby Cywilnej będzie m.in. opiniowanie zmian w prawie dotyczącym służby cywilnej, ale też ocena przebiegu postępowań kwalifikacyjnych. 
Administracje publiczne krajów członkowskich UE podlegają nowym wyzwaniom związanym $\mathrm{z}$ integracją europejską. W literaturze przedmiotu podkreśla się zjawisko europeizacji administracji publicznej, które polega na związkach między administracjami publicznymi państw członkowskich i między tymi państwami a instytucjami europejskimi ${ }^{44}$. W konsekwencji prowadzi to do standaryzacji służb cywilnych w państwach członkowskich. Efektywna administracja w zakresie stosowania prawa europejskiego wymaga modyfikacji wewnętrznych struktur administracji, tak aby w sposób skuteczny wprowadzać w życie postanowienia instytucji europejskich. Komisja Europejska już w fazie oceniającej stopień przygotowania Polski do integracji europejskiej, zaleciła podnoszenie kwalifikacji urzędników w sprawach europejskich i efektywności zarządzania europejskiego, wypracowanie strategii szkolenia urzędników oraz zapewnienie równego dostępu obywateli do służby cywilnej ${ }^{45}$. Niewątpliwie nowym wyzwaniem dla Polski w ramach swobody przepływu pracowników (za wyjątkiem ograniczenia odnośnie stanowisk związanych ze sprawowaniem władzy lub ochroną interesów państwa) jest sklasyfikowanie stanowisk, zapewnienie wzajemnego uznania kwalifikacji i doświadczenia zawodowego czy utworzenie porównywalnych płac i dokonania zmian w systemie emerytalnym. W tym względzie pomocne mogą być m.in. wnioski płynące ze Wspólnej Metody Oceny, czyli instrumentu oceny jakości zarządzania w administracji publicznej państw członkowskich Unii Europejskiej. Założenia projektu nowelizacji ustawy o służbie cywilnej (2008 r.) dotyczą jawnego i równego dostępu do stanowisk publicznych, stworzenie spójnego systemu zarządzania kadrami w służbie cywilnej oraz dostawanie jej do standardów konstytucyjnych. Niewątpliwie zmiany te jeszcze bardziej przybliżą nasz polski model urzędniczy do rozwiązań administracyjnych preferowanych w instytucjach Unii Europejskiej.

\section{Summary}

The civil services in Poland and EU institutions undergo similar processes. France (at the time of the $3^{\text {rd }}$ Republic) was the cradle of civil service, therefore the administrative systems of Western Europe (and others) have sought examples there. The Polish model of civil service can be described as a mixed one, with the prevalence of regulations typical of a career model. In the career model the state is the master that employs

44 J. Czaputowicz, op. cit., s. 261-262.

45 Ibidem, s. 274-275. 
a servant. Similar solutions are applied in France, Germany and Austria. They have been modified for the purpose of the specific functions which the civil service performs in EU institutions (a so-called closed career model). In the position system, particular authority is granted the civil servant's employer rather than the state as a whole. A civil servant is employed in a particular position rather then in the civil service 'in general'. The stability of employment and guarantee of remuneration are lower. The UK, Nordic countries and Italy apply solutions that are similar to this model. 